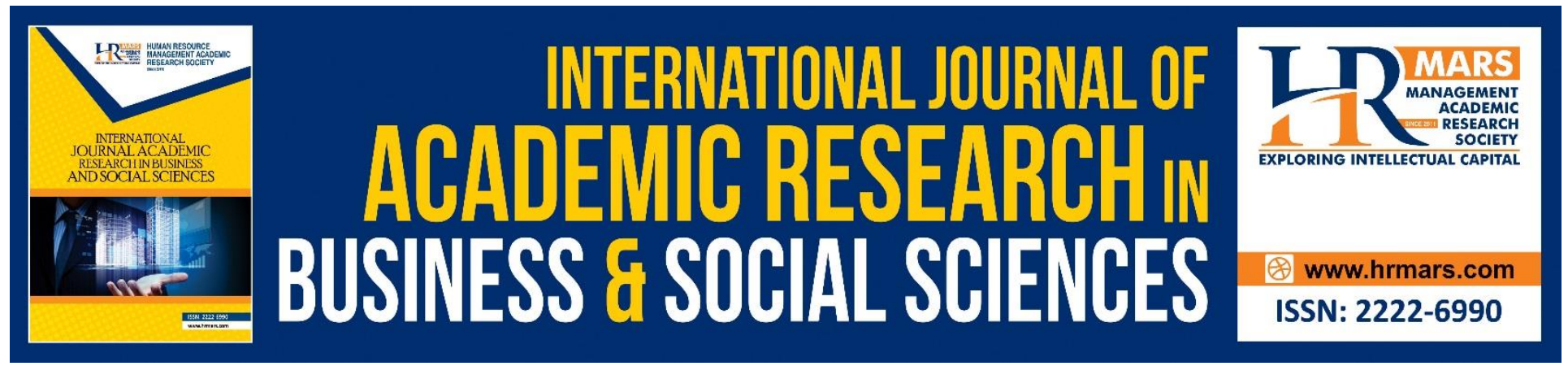

\title{
The Use of Humanoid Robotic as Assistive Rehabilitation Treatment for Children with Autism According to Objectives of Shariah in Islam
}

Amily Fikry, Siti Fatahiyah Mahamood, Nor Lelawati Jamaludin, Intan Syafinaz Mat Shafie, Zarith Delaila Abd Aziz, Yuslina Liza Mohd Yusof, Nor Irvoni Mohd Ishar, Mohd Nor Mamat

To Link this Article: http://dx.doi.org/10.6007/IJARBSS/v10-i7/7400

DOI:10.6007/IJARBSS/v10-i7/7400

Received: 13 April 2020, Revised: 16 May 2020, Accepted: 24 June 2020

Published Online: 22 July 2020

In-Text Citation: (Fikry et al., 2020)

To Cite this Article: Fikry, A., Mahamood, S. F., Jamaludin, N. L., Shafie, I. S. M., Aziz, Z. D. A., Yusof, Y. L. M., Ishar, N. I. M., \& Mamat, M. N. (2020). The Use of Humanoid Robotic as Assistive Rehabilitation Treatment for Children with Autism According to Objectives of Shariah in Islam. International Journal of Academic Research in Business and Social Sciences, 10(7), 116-129.

Copyright: (c) 2020 The Author(s)

Published by Human Resource Management Academic Research Society (www.hrmars.com)

This article is published under the Creative Commons Attribution (CC BY 4.0) license. Anyone may reproduce, distribute, translate and create derivative works of this article (for both commercial and non-commercial purposes), subject to full attribution to the original publication and authors. The full terms of this license may be seen

at: http://creativecommons.org/licences/by/4.0/legalcode

Vol. 10, No. 7, 2020, Pg. 116 - 129

http://hrmars.com/index.php/pages/detail/IJARBSS

JOURNAL HOMEPAGE

Full Terms \& Conditions of access and use can be found at http://hrmars.com/index.php/pages/detail/publication-ethics 


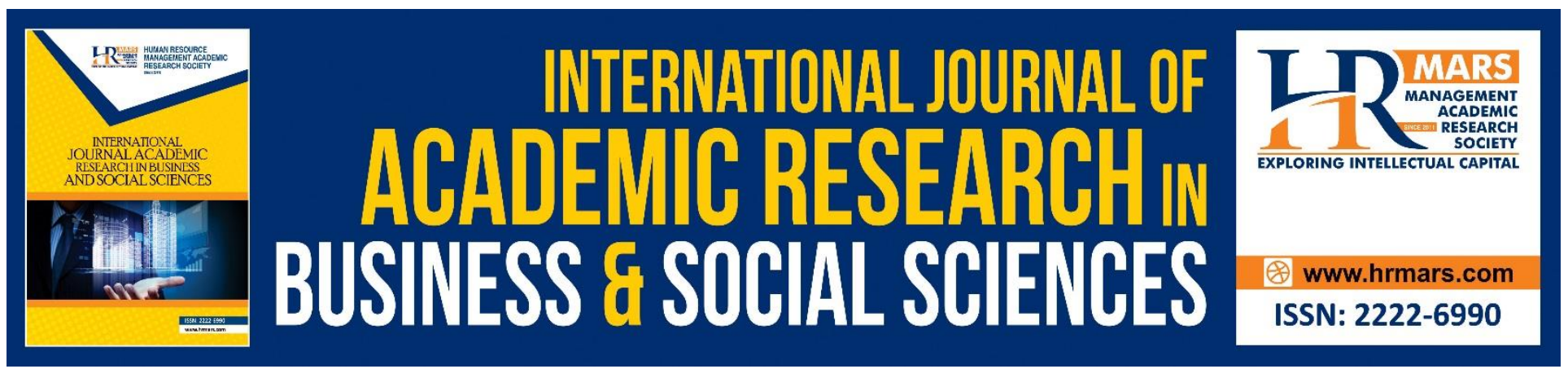

\title{
The Use of Humanoid Robotic as Assistive Rehabilitation Treatment for Children with Autism According to Objectives of Shariah in Islam.
}

\author{
Amily Fikry ${ }^{1}$, Siti Fatahiyah Mahamood ${ }^{2}$, Nor Lelawati Jamaludin ${ }^{3}$, \\ Intan Syafinaz Mat Shafie ${ }^{4}$, Zarith Delaila Abd Aziz ${ }^{5}$, Yuslina Liza \\ Mohd Yusof ${ }^{6}$, Nor Irvoni Mohd Ishar ${ }^{7}$, Mohd Nor Mamat ${ }^{8}$. \\ 1,3,4,5,6 Faculty of Business and Management, Universiti Teknologi MARA Campus Selangor, 42300 \\ Puncak Alam, Selangor, Malaysia, 1,2,3,4,5,6,7,8,Islamic Digital Marketing Research Group, Universiti \\ Teknologi MARA,40450 Shah Alam, Selangor, \\ ${ }^{2,8}$ Academy of Contemporary Islamic Studies, Universiti Teknologi MARA, 40450 Shah Alam, \\ Selangor, Malaysia, ${ }^{7}$ Arshad Ayub Graduate Business School, Universiti Teknologi MARA, 40450 \\ Shah Alam, Selangor, Malaysia \\ Email: amily@uitm.edu.my, amilyfikryaziz@gmail.com
}

\begin{abstract}
The increasing rate of the number of children with Autism showed the importance to focus on ways to reduce the symptoms faced by the children with Autism. Noting the scarcity of research focusing on this area, this paper aims to review the use of humanoid robotics as an assistive rehabilitation treatment for children with Autism according to objectives of shariah in Islam. Content analyses through literature search from the online database were used as a basis for this review paper write-up from main sub-fields of humanoid robotics, assistive rehabilitation treatment for children with Autism and objectives of shariah in Islam. The researchers also follow the four-step process model derived from Mayring (2008), forming the process model of (qualitative) content analysis. Based on the paper, it was found that the framework of objectives of shariah in Islam which includes the Islamic Principles in treatment and rehabilitation are tailored according to Shariah Law to moderate and tolerate the balances between the new technology and the help from the therapists through the potential behavioural and cognitive changes associated with a single exposure to the humanoid. This paper believes that upon incorporating the protection of the five necessary intents of objectives of shariah in Islam, the humanoid will be able to help those children with autism to gain a better life.
\end{abstract}

Keywords: Autism, Humanoid, Rehabilitation.

Introduction

Many people out there might not be even aware of the earlier signal of those with peculiar behaviour within themselves if the medical expert has not diagnosed it. Tantrum behaviour that might seem 
reasonable at an early age when in turns become uncontrollable could lead to average deficit growth. Autism Symptom Disorders (ASD) is a formative issue that influences communication and behaviour. Even though mental imbalance can be analyzed at any age, it is said to be a "development disorder" since the symptoms show up in the initial two years of life.

The circumstances of individuals diagnosed with an ASD may be particularly important to consider when examining purpose development (Brandy et al. 2019). Two areas which may relate to the purpose development are either ASD children could frustrate or enhance their development of purpose. Some of the ASD children may have different ability and challenge. One may lose the ability to stay focus for an extended period, one may have a challenge in taking perspective. As it were, the reason may look both comparative and different among those people determined to have an ASD when contrasted with existing findings about reason among neurotypical people. Children with ASD too are facing difficulty learning social rules. Another study that examined trust-building in adults with ASD confirmed difficulty in social learning, mainly encoding incoming social information and applying it to update social expectations (Maurer et al. 2017).

It is essential to understand the experiences of individuals with ASD; it is also essential to understand how the presence of an ASD impacts others C.M. Shivers (2019). Degree of the difficulty may differ among themselves when it involves impairment not only in mental but impairment in emotional state attribution.

\section{Literature Review}

\section{Defining Autism Spectrum Disorder}

Autism spectrum disorder is an increasingly common diagnosis which is currently at an all-time high of 1 in 59 children in the United States (Baio et al. 2018; Centres for Disease Control and Prevention 2018), with about 47000 children suffering from it in Malaysia alone (Rofiza et al. 2018). ASD is defined in the Diagnostic and Statistical Manual of Mental Disorders, 5th edition (DSM-5), as "persistent deficits in social communication and social interaction across contexts" (American Psychiatric Association, 2013). Children with ASD may have (Diagnostic and Statistical Manual of Mental Disorders (DSM-5), 2013):

(1) difficulty with communication and interaction;

(2) restricted interests and repetitive behaviors; and

(3) the ability to function properly in school, work, and other areas of life

Autistic children suffer from multifaceted deficiencies in social interaction, communication skills and physical skills (American Psychiatric Association, 2000) besides showing disruptive behaviours (Ozdemir, 2008), having unique obsessions (American Psychiatric Association, 2000), hyperactive, behaviours of self-injury, disparities of mood and in eating, and also compulsions (Sitimin, et al., 2017).

According to Tordjman et al. (2019), ASD shares social communication impairments that may rely partly on self-consciousness disorders. Self-consciousness can be a significant factor and a cause of a lack of self-confidence. In this relation, it justifies children with ASD who are only comfortable with an awareness of one's own identity. Children with ASD associated with the inability to function and slow growth in maturity. Abnormal functional activation and maturation of ventromedial prefrontal cortex during temporal discounting were reported in ASD (Murphy et al. 2017). The other abnormal symptom is also can be seen in their signal gating. A study by (Chantel et al. 2016; Prat et 
al. 2016) found an abnormal signal gating to prefrontal cortex has also been reported in ASD with basal ganglia impairments.

ASD shows a decreased growth in development and difficulties in social communication with restricted and repetitive behaviour (RRB). RRB comes from a different area. Apart from having difficulties to function, the ASD children tend to have reducing external stimuli and to avoid communication. They do not know how to cope with stress, distress, and excitement. Nevertheless, social and communication skills, too at jeopardize when dealing with ASD children. According to Manor-Binyamini and Schreiber Divon (2019) in their study, abnormal processing mechanisms cause emotional-cognitive-sensory imbalances and an internal sense of chaos, leading to the need for external order and control of the body and environment. Thus, by having RRBs helps ADS children cope with internal chaos. In other research suggests that RRBs, in particular, can vary across cultures and that cultural norms may play a significant role in how parents perceive the atypicality and severity of RRB (Matson et al. 2017).

\section{Defining Humanoid Robotic and its use in Rehabilitation Treatment}

Zooming to the use of humanoid robotic as rehabilitation assistive treatment, there are two main categories of rehabilitation robot system, namely therapy robots (being subdivided into physical therapy and emotional therapy robot) and assistive robots (being described as physical/social interaction robots) (Yakub et al. 2014). In assistive robots, i.e. physical/social interaction robots, one of the examples of social interaction robots is the helper robot which may take on the form of a machine-like device (such as an auto vacuum) or human-like robots (such as humanoid).

Various type of humanoid robots with different attribute and appearance, advancement in method and system has been invented recently in various field such as education, medicine and rehabilitation (Hashim et al. 2017; Gunawan et al. 2018). Linert and Kopacek (2018) categorized humanoid robots in four categories; Robotainment (Fluffy), Infosistance (Buddy), Rescue (Hero) and Intelligent robots ( $\mathrm{Mr}$ Brain) with which each of the categories performed different functions. For instance, $\mathrm{Mr}$ Brain robots that combine human mobility and artificial intelligence has been used for autism treatment (Robot NAO (developed by Aldebaran Robotic) and Alice (manufactured by Robokind)) (Taheri et al. 2015; Zhang et al. 2019) and robots with essential self awareness (Popsci.com, 2015) and implementation of bioinspired decision making system (DMS) to improve the Human-robot interaction (HRI) (Pe'rula-Martinez et al. 2019).

According to Zhang et al. (2019), humanoid robots known as social robots that have a humanlike appearance with fabrication of a human body and behavioral characteristics that mimicking the human behavior (Raffard et al. 2016) which include verbal and non-verbal behavioral cues such as gazing and gestures, body postures, facial emotions and proxemics (Tapus et al. 2019). There are three main features of humanoid robots; biped walking, voice communication/ speech recognition and facial communication (Linert et al. 2018).

In another research, humanoid robots have been recognized as ecology robots (Tapus et al. 2019), and a new term is known as "Robotainment" has been introduced to named it (Linert et al. 2018). Meanwhile, in rehabilitation, humanoid robots also referred to as Socially Assistive Robots (SARs) that assists patients via social interaction and providing innovative tools for rehabilitation (Langer et al. 2019). 
INTERNATIONAL JOURNAL OF ACADEMIC RESEARCH IN BUSINESS AND SOCIAL SCIENCES Vol. 10, No. 7, July, 2020, E-ISSN: 2222-6990 @ 2020 HRMARS

\section{Humanoid Robots and Its use in Rehabilitation}

Zooming to the use of humanoid robots in rehabilitation, humanoid robots are believed to ease and assist society in the present future. Humanoid robots play a substantial role in our society to make life more convenient (Gonzalez-Jimenez, 2018). Such as in education, healthcare and in the rehabilitation of elderly and children to aid in tasks for disabled people such as Cerebral Palsy (CP) ,Autism Spectrum Disorders (ASD) (Syamimi et al. 2012; Zhang et.al 2019; Anzalone et al. 2019), patients with schizophrenia (Raffard et al. 2016) and people who suffer from speech or cognitive impairments (Langer et al. 2019).

Moreover, humanoid robots also have been mentioned as one of the tools to aid children with multiple disabilities such as movement disabilities, sensory loss and behaviour or emotional disorder (Wang et al. 2016) and children with the oncological disorder (Meyns et al.2019). Humanoid robots assist children in a clinical population in teaching and therapy session (Anzalone et al., 2019), give motivation (Meyns et al., 2019) as well as to support improvements in social skills (Zhang et al. 2019).

\section{Autism Spectrum Disorder and Humanoid Robotic Therapy}

Several types of treatments have been used to reduce the symptoms faced by these children with autism, ranging from medical consumption and non-medical attempts such as acupuncture (Chen et al. 2019), horse therapy (Grandin, 2019) and humanoid robotic as rehabilitation assistive treatment (Robins et al. 2005; Lorenzo et al. 2018; Shamsudin et al. 2012; Wood et al. 2019).

Researchers have been focusing on using humanoid robotics as an assistive rehabilitation treatment for children with ASD starting from the late 1990s (Wood et al. 2019). These humanoid robots are used as social mediators to help facilitate and promote social communication, interaction for children with ASD (Wood et al. 2019) and behavioural skills thus improving symptoms of patients with ASD. Humanoid robots are being used as an assistive rehabilitation treatment for ASD due to user acceptance and trust towards the robots. The user acceptance also differs according to the individual due to the factor of age, gender and health condition of the user himself. For example, children with ASD prefer to interact with a humanoid robot as compared to human himself since these humanoid robotic is being treated like a toy or friend to them (Choudury, 2018).

The first robot being used is a doll-like robot called Robota and later on followed by Kaspar. Other humanoid robots that have been used as part of assistive rehabilitation treatment for children with ASD are NAO, PROBO and Zeno (Wood et al. 2019). Although humanoid robot has been used as part of assistive rehabilitation treatment for children with ASD, one must not ignore the human assistance such as parents of ASD child, therapist and or teachers who act as a mediator in using a humanoid robot to treat these ASD children (Wood et al. 2019).

\section{Religiosity and Spiritual Aspects of Humanoid Robotic Therapy}

The use of humanoid robotics as part of the rehabilitation therapy (or the so-called Rehabilitation Robot System) for children with Autism has been vastly studied (Robins et al. 2005; Lorenzo et al. 2018; Shamsudin et al. 2012; Wood et al. 2019). Past studies such as Kimura (2015) were focusing on the Buddhist philosophy of robot and its ethical design while the study of Mahamood et al. (2017) focusing on the use of humanoid robotic for brain impairment in accordance to Islamic Principles, thus partially related to the research at hand. In another, Hashim et al. (2016) reviewed the perceptions on the use of robots for spiritual augmentation of special-needs children within the 
context of the Islamic faith and discovered that humanoid robotics could not replace human beings. The religious teaching and spiritual enhancement need to perform by a human being, and cannot rely on humanoid robotic to do so. Weng et al. (2019) focused on the impact of Taoist religion towards ethically aligned design in future human-robot interaction.

Looking at the impact of religiosity or spiritual aspects therapy in Indonesia, Liem (2019) found that ASD children and adolescent clients would be more effectively treated with conventional medicine rather than spiritual, religious therapy such as dukun or spiritual healer. The research conducted by Liem (2019) only covered on spiritual aspects on ASD but did not touch on humanoid robotics, thus it is only partially related to research at hand. Tanhan (2019) highlights the use of Acceptance and Commitment Therapy (ACT) amongst Muslims and parents with ASD child, but the research does not relate with humanoid robotic thus only partially related to the research at hand.

According to Deuraseh (2012), it is necessary to accept 'the protection of human health' as a fundamental value in objectives of shariah in Islam, or the so-called Maqasid Shariah. As we know, health is one of God's greatest blessing, bestows to humankind. Surely, worship cannot be achieved without good health and well-being. Abu al-Darda' r.a voiced to the Prophet says: 'To be healthy and grateful is much better than to be ill and endure patiently', the Prophet saw answered him by saying: "Allah loves healthy people, as you do" (Ibn al-Qayyim, 1988). In order to support this, Ibn al-Qayyim (d. 750 A.H/ 1350 C.E), in his book al-Tibb al-Nabawi, mentions and stresses that: good health, strength, and well-being are the most prized, precious, and generous gifts.

Islam provides a law of dos and don'ts called Shariah. Scholars who examined Shariah rules observed that essentially all dos and don'ts that are in Shariah are for protection and continuity of human society. They found that these rules are there for the protection of five aspects of objectives of shariah in Islam. Protections mentioned here are not for one-time protection. They are also not restricted to protection against degradation from the current level of each dimension, for example, the dimension of life in whatever way it is measured, but they are also about enhancement and improvement. In fiqh terminology, it is about daf al-mafasid (removal of degrading factors and constraints) jalb al-masaleh (attainment and enhancement of benefits) (Ali et al. 2011). Thus, for example, protection of self (or life) can include protection against the attack of life, disease, unhealthy living conditions, loss of dignity, hunger, poverty or others.

\section{Objectives of Shariah in Islam and Humanoid Robotic Therapy}

The use of humanoid robotics for assistive treatment for children with Autism following objectives of shariah in Islam is very scarce. Thus this research aims to review the use of humanoid robotics as an assistive rehabilitation treatment for children with Autism according to objectives of shariah in Islam. According to Abdullah S. (2012), objectives of shariah in Islam is vitally necessary to be delineated to provide an understanding of the rationale of the Shariah guidelines for the humankind to live in this world according to the Islamic way of life. Indeed, objectives of shariah in Islam enables a better appreciation of Islam as well as a comprehensive appreciation of the Almighty's rules and regulation. objectives of shariah in Islam is classified according to different dimensions: the traditional classification of objectives of shariah in Islam is according to the levels of necessity, the scope of the rulings to achieve the purpose, scope of people included in the purpose, and level of universality of the purpose. The modern or contemporary scholars classify objectives of shariah in Islam according to general objectives, specific objectives and partial maqasid (Auda, 2008). 
Objectives of shariah in Islam refers to the objectives of Shariah to ensure welfare to humankind, while Shariah means Islamic Law. There are five primary intents of objectives of shariah in Islam, namely preservation of religion, life, progeny, intellect and wealth. Health care in general, or in this particular study treating children with Autism with the assistance of humanoids robotics, seems to be intricately associated with the preservation of both progeny and intellect. Hence, to treat a patient through medication and therapy is a subject matter inseparable from shariah and its maqasid (Mahamood et al. 2017). Due to the sacred of life and all moments in life have great value. Therefore the saving of life and to heal from any illness should be done to take care of both progeny and intellect. In the Qur'an, Allah said: "O ye who believe! Make not unlawful the good things which Allah hath made lawful for you, but commit no excess: for Allah loveth not those given to excess. Eat of the things which Allah hath provided for you, lawful and good; but fear Allah, in Whom ye believe."(Al-Maidah, Verses 87-88).

In order to preserve the five primary intents, it should be done by following the Islamic Principles in treatment and rehabilitation. Muslims should find ways to heal their sickness, then only they should leave to God to grant them with cure (Al-Jauziyah, 2010, pp. 30-34). Thus, the statement "the ends justify the means" is not practised in Islam. Muslims incorporate their religion in every angle to fulfil the needs in their lives and focus on the availability of God to monitor all their actions. Therefore, Muslims believe that they should take care of the five objectives of shariah in Islam to live harmoniously in this world and have good lives in the HereAfter.

From an Islamic perspective, the decisions on the actions to be taken to achieve a particular objective must always be based on the Islamic Principles. Fatahiyah et al. (2010) found that in aspects related to medicine, there are six major principles to be followed. These six significant principles are:

(1) The treatment goes in line with the teachings of Islam;

(2) The treatment is based on the Islamic Legal Maxims;

(3) The treatment focuses on the prevention and cure;

(4) Avoid doing destructions;

(5) Believe in the power of Allah to cure every illness; and

(6) Use an unlimited method of treatment which is shariah compliant.

Muslims believe that all their actions have been accountable and are subjected to ultimate judgement as stated in the Qur'an in Surah Al-Maidah, verse 85: "Whoever recommends and helps a good cause becomes a partner therein: And whoever recommends and helps an evil cause, shares in its burden: And Allah hath power over all things."

On the other hand, the making of a robot falls under the ruling of image-making. If the robot resembles precisely the shape of a man or any animate being with the purpose to be worshipped or adored without any urgency, it is prohibited in Islam. It is associated with the action of imitating Allah's creation (Mahamood et al. 2017). "Give life to that which you have created." It also comes with the words of the Prophet (peace and blessings of Allah be upon him): "Those who will be most severely punished on the Day of Resurrection will be the image-makers." (Narrated by al-Bukhaari, no. 5606; Muslim, 2109). Therefore, the use of humanoid robotics as an assistive rehabilitation treatment for children with autism fulfils the requirements of objectives of shariah in Islam and the Islamic Principles in treatment and rehabilitation. 
INTERNATIONAL JOURNAL OF ACADEMIC RESEARCH IN BUSINESS AND SOCIAL SCIENCES

Vol. 10, No. 7, July, 2020, E-ISSN: 2222-6990 @ 2020 HRMARS

\section{Methodology}

Content analyses through literature search from the online database were used as a basis for this review paper write-up. Utilizing applying content analysis, the paper reviews literature reviews of various inductively derived sub-fields of humanoid robotics, assistive rehabilitation treatment for children with Autism and objectives of shariah in Islam. The criterion for inclusion into the sample of papers was that at least two reviews of the respective sub-fields had been published in relevant English-speaking peer-reviewed journals in the twenty-year-period between 1999 and 2019. The findings of this content analysis and several methodological discussions aim at providing some practical guidance for the researcher. In this paper, the broad scope of content analysis can be translated into two levels of analysis:

The first level analyses the manifest content of texts and documents by statistical methods. On a second level, the latent content of the text and documents is excavated requiring interpretation of the underlying meaning of terms and arguments. It is a specific strength of content analysis that this method can combine qualitative approaches retaining rich meaning with robust quantitative analyses (Duriau et al. 2007), where it seems meaningful for the analyst (Mayring, 2000).

Referring to Mayring (2008), one may distil four main steps forming the process model of (qualitative) content analysis(Kassarjian,1977; Krippendorff, 1980; Mayring, 2000):

(1) the material to be analysed is delimitated, and the unit of analysis is defined (material collection);

(2) formal characteristics of the material are assessed, providing the background for subsequent content analysis (descriptive analysis);

(3) structural dimensions and related analytic categories are selected, which are to be applied to the collected material (category selection); and

(4) the material is analysed according to the (analytic) dimensions (material evaluation).

Kassarjian (1977) stipulates that content analysis should follow a clear and purposeful process structure; accordingly, we follow the four-step process model derived from Mayring (2008) as introduced above. Kassarjian (1977) stipulates that content analysis should follow a clear and purposeful process structure; accordingly, the researchers follow the four-step process model derived from Mayring(2008) as introduced above. Our literature sample comprises English-speaking peer-reviewed literature review papers on assistive rehabilitation treatment for children with autism and objectives of shariah in Islam covering the twenty-year-period from 1999 to 2019. Peer-reviewed journal articles represent a significant mode of communication among researchers; therefore, they are taken as a unit of analysis. For compiling the paper sample, a literature search was carried out, based on the pair of keywords " objectives of shariah in Islam", "assistive rehabilitation treatment in autism" and "humanoid robotic", to be jointly found in title, keywords or abstract. The structured keyword search was conducted in major databases and library services: Emerald (www.emeraldinsight.com), Springer (www.springerlink.com), Wiley(www.wiley.com), and Scopus (www.scopus.com). Depending on whether a sufficient sample is reached at the title, abstract and keywords level, the selection of papers might either be narrowed or extended beyond this. Subsequently, different processing steps might be needed for ensuring that identified papers deal with the topics addressed. This has to be sure by reading the papers and thereby reflecting on their appropriateness for the topic studied. The criterion for inclusion into the paper sample was that at least two reviews of one subfield had been published within the relevant timespan. Current literature 
INTERNATIONAL JOURNAL OF ACADEMIC RESEARCH IN BUSINESS AND SOCIAL SCIENCES

Vol. 10, No. 7, July, 2020, E-ISSN: 2222-6990 @ 2020 HRMARS

representing the relevant information was also searched for in other online databases and websites. Altogether, we identified 50 papers dispersed over ten journals.

Moreover, for all studies in this literature search phase, attention is directed to two types of relevant information:

(1) Findings from previous studies that focus on humanoid robotics, assistive rehabilitation treatment for children with Autism and objectives of shariah in Islam

(2) Theories and concepts adopted by previous studies when examining assistive rehabilitation treatment according to objectives of shariah in Islam

\section{Result and Discussion}

To respond to new medical technology, Humanoids, such as NAO, are now available in the market and are used for both typical and atypical developing children. Studies on the initial response of children with autism have led to a promising field of advancement in managing children with this disability (Mahamood et al. 2017). Two studies (Hashim et al. 2013) and (Shamsuddin et al. 2012) looked at the potential behavioural and cognitive changes associated with a single exposure to the humanoid robot NAO.

In Malaysia, Islam plays a very crucial role in looking at all angles of solutions as Muslims are the majority of the population. The framework of objectives of shariah in Islam and the Islamic Principles in treatment and rehabilitation and preserve life and faith. In detailing the level of objectives of shariah in Islam according to al-Shatibi (Al-Raysuni, 2005), it consists of three categories, namely:

(1) urgency (ad-dharuriyyat): guaranteeing their 'vital needs;

(2) necessity (al-hajiyat): catering for their 'requirements; and

(3) additional facilities or luxuries (at-tahsiniyyat): allowing for 'betterment', enhancement or improvements (tahsiiniyaat) in the quality of their life.

He mentioned that the overall objective of Islamic law is to populate and civilize the earth and preserve the order of peaceful coexistence therein. To ensure the earth's ongoing well-being and usefulness through the piety of those who have been placed there as God's vicegerents. To ensure that people conduct themselves justly, with moral probity and with integrity in thought and action, and to reform that which needs reform on earth, that they tap its resources and plan for the good of all. Scholars like Al-Ghazali, Ibn al-Hajib and al-Shatibi defined daruriyyah as the preservation and safeguarding of five fundamentals in one's life that includes protection of religion (din), protection of life (nafs), protection of intellect (aql), protection of wealth (mal), and protection of lineage (nasl). These are regarded as the essential needs that a man requires for his well-being in this world and the hereafter. None of these essential needs can be ignored, for it will create a disorder in this world and man will not be able to fulfil his requirement as a khalifah in this world and achieve success in the world hereafter (Ibn Ashur, 2006). This classification shows the full range of dimensions and varieties of objectives of shariah in Islam which aim to provide ease and eliminate or reduce hardship to the society, especially to the Muslims.

Thus, the use of humanoid robotics as an assistive rehabilitation treatment for children with Autism falls under the level of urgency because these children have to undergo intervention and rehabilitation. This fulfils the requirement of five primary intents of objectives of shariah in Islam and meets the six Islamic Principles in treatment and rehabilitation requirements. 


\section{Conclusion}

Our point of departure for this study was that the framework of objectives of shariah in Islam that includes the Islamic Principles in treatment and rehabilitation which are tailored according to Shariah Law can further moderate and tolerate the balances between the new technology and the help from the therapists through the potential behavioural and cognitive changes associated with a single exposure to the humanoid. This approach could be developed further to offer new insights into research on humanoid robotic as assistive rehabilitation treatment for children with autism beyond seeing the framework of objectives of shariah in Islam as predictors. However, the researchers believe much more research is needed in order to explain relational exchanges in this context, given the present competitive context in which they are now immersed. Nevertheless, based on the findings, it can be suggest that the framework of objectives of shariah in Islam and Islamic Principles in treatment and rehabilitation can be used as one of the alternative interventions to moderate and tolerate the balances between mind and soul, material and spiritual and also between ethics and jurisprudence. The importance of preventing illness and healing should be taken into account.

This study presents an overview of the state-of-the-art solutions for helping and assisting children with autism spectrum disorders by means of diagnosis and social therapies following Shariah Law. These solutions benefit from new advances in artificial intelligence, as these increases the autonomy levels of assistance robots promoting children with autism spectrum disorder's daily functioning, well-being, and independence.

Indeed, Mahamood et al. (2017) affirmed that humanoid robots are not made to replace humans or healthcare professionals in providing therapy and care. The humanoids are merely an augmentation of therapy, providing a new approach in increasing the awareness, attention, and participation of the brain-impaired. The features of the humanoid are inclined towards simplicity and are necessary to help process information during learning and rehabilitation. Without this aid, the hardship of being brain-impaired may be prolonged.

The researchers believe that the current study provides some insights into the potential of incorporating the protection of the five necessary intents of objectives of shariah in Islam in assistive rehabilitation treatment for children with autism. By doing this, the humanoid will be able to help children with autism to gain a better life. Additionally, despite the exploratory nature of this study, the findings add insights to the psychology of children with autism and improve knowledge about the use of humanoid robotic as assistive rehabilitation treatment for children with autism according to objectives of shariah in Islam. We acknowledge that the current intervention does not provide ideal solutions to all needs of people with disabilities, but the results are highly promising.

\section{Acknowledgments}

The researchers would like to acknowledge the Faculty of Business and Management, Universiti Teknologi MARA Campus Selangor, Puncak Alam, for the fund received through Grant Project title: Exploring The Use Of Humanoid Robotic As Assistive Rehabilitation Treatment For Children With Autism According To Maqasid Syariah; Project File No: 600-IRMI 5/3/DDF (FPP) (025/2019). Utmost thanks go to the faculty and members of the team for the excellent support to internalise the objectives of this study. 
INTERNATIONAL JOURNAL OF ACADEMIC RESEARCH IN BUSINESS AND SOCIAL SCIENCES

Vol. 10, No. 7, July, 2020, E-ISSN: 2222-6990 @ 2020 HRMARS

\section{References}

Abdullah, S. (2012). Risk management via Takaful from a perspective of Maqasid of Shariah. ProcediaSocial and Behavioral Sciences, 65, 535-541.

Ali, S. S., and Hasan, H. (2011). Towards a maqasid al-shariah based development index. Measurement, 95, 7-8.

Anzalone, S. M., Xavier, J., Boucenna, S., Billeci, L., Narzisi, A., Muratori, F., Cohen, D., and Chetouani, M. (2019). Quantifying patterns of joint attention during human-robot interactions: An application for autism spectrum disorder assessment. Pattern Recognition Letters, 118, 42-50.

American Psychiatric Association. (2000). Diagnostic and statistical manual of mental disorders. Washington, DC: American Psychiatric Association.

American Psychiatric Association. (2013). Autism spectrum disorder. Diagnostic and statistical manual of mental disorders. ( $5^{\text {th }}$ ed.), 50.

American Psychiatric Association. (2013). Diagnostic and statistical manual of mental disorders (DSM5). (5 $5^{\text {th }}$ ed.)

Al-Raysuni, A. (2005). Imam Al-Shatibis Theory of the Higher Objectives and Intents of Islamic Law. London: IIIT.

Auda, J. (2008). Maqasid Al-Shariah: A Beginner s Guide. London: IIIT.

Bakar, R. A. (2019). Understanding Support For Parents Of Autistic Children Through A Whatsapp Group. Paper presented at the ASIA Proceedings of Social Sciences

Baio, J., Wiggins, L., Christensen, D. I., Maenner, M. J., Daniels, J., Warren, Z., Kurzius-Spencer, M., Zahorodny, W., Rosenberg, C. R., White, T., and Durkin, M. S. (2018). Prevalence of autism spectrum disorder among children 8 years - autism and Development Disabilities Monitoring Network, 11 sites, United States, 2014. Surveillance Summaries, 67, 1-23. Available at: <http://dx.doi.org/10.15585/mmwr.ss6706a1> [Accessed 10 May 2020].

Carolyn, M. S. (2019). Empathy and perceptions of their brother or sister among adolescent siblings of individuals with and without autism spectrum disorder. Research in Developmental Disabilities. 92, 103451.

Centres for Disease Control and Prevention. (2018). Autism Spectrum Disorder (ASD). Data and Statistics. Available at: <http://www.cdc.gov/ncbddd/autism/data.html> [Accessed 10 May 2020].

Chen, W.-X., Liu, G., Liu, H.-S., Huang, Z.-F., Yang, S.-Y., Huang, J., and Wu, Q. Q. (2019). Acupuncture for Non-Verbal Autistic Children: Randomized Controlled Trial. Neuropsychiatry (London), 9, 2056-2069.

Choudhury, A., Li, H., Greene, C. M., and Perumalla, S. (2018). Humanoid Robot-Application and Influence. Archives of Clinical and Biomedical Research, 2, 197-226.

Desideri, L., Negrini, M., Malavasi, M., Tanzini, D., Rouame, A., Cutrone, M. C., and Hoogerwerf, E. J. (2018). Using a humanoid robot as a complement to interventions for children with autism spectrum disorder: a pilot study. Advances in Neurodevelopmental Disorders, 2, 273-285.

Deuraseh, N. (2012). New essential values of daruriyyah (necessities) of the objectives of islamic law (Maqasid Al-Shariah). Jurnal Hadhari: An International Journal, 4, 107-116.

Gonzalez-Jimenez, H. (2018). Taking the fiction out of science fiction: (Self-aware) robots and what they mean for society, retailers and marketers. Futures, 98, 49-56.

Grandin, T. (2019). Case study: how horses helped a teenager with autism make friends and learn how to work. International Journal of Environmental Research and Public Health, 16, 1-5. 
INTERNATIONAL JOURNAL OF ACADEMIC RESEARCH IN BUSINESS AND SOCIAL SCIENCES

Vol. 10, No. 7, July, 2020, E-ISSN: 2222-6990 @ 2020 HRMARS

Gunawan, A. A. S., Mulyono, P. R., and Budiharto, W. (2018). Indonesian question answering system for solving arithmetic word problems on intelligent humanoid robot. Procedia Computer Science, 135, 719-726.

Hashim, R., Yussof, H., and Bahrin, N. L. Z. (2017). Religious perceptions on use of humanoid for spiritual augmentation of children with autism. Procedia Computer Science, 105, 353-358.

Hennessey. (2019). Purpose in adolescents diagnosed with an autism spectrum disorder. Journal of Adolescence. 73, 53-62. Available at: <https://doi.org/10.1016/j.adolescence.2019.03.001> [Accessed 10 May 2020].

Ibn Ashur, M. A. (2006). Treatise on Maqasid al-Shariah, translated by Dr.Muhammad El-Tahir ElMesawi. London: IIIT.

Linert, J., and Kopacek, P. (2018). Humanoid Robots Robotainment. IFAC PapersOnLine, 51, 220-225. Kassarjian, H. H. (1977). Content analysis in consumer research, The Journal of Consumer Research, 4, 8-18.

Kimura, T. (2015). Masahiro Mori's Buddhist philosophy of robot. Paladyn, Journal of Behavioral Robotics, 9, 72-81.

Langer, A., Feingold-Polak, R., Mueller, O., Kellmeyer, P., and Levy-Tzedek, S. (2019). Trust in socially assistive robots: Considerations for use in rehabilitation. Neuroscience and Biobehavioral Reviews, 104, 231-239.

Lindgren, S., and Doobay, A. (2011). Evidence-based interventions for autism spectrum disorders. The University of lowa.

Mahamood, S. F., and Hanapiah, F. A. (2017). Merging the research on halal concept using humanoids for patient with brain-impairment: its maqasid and principles. Pertanika Journal Social Science and Humanities, 25(S), 209-216.

Matson, L., Matheis, M., Burns, O., Esposito, G., Venuti, P., Pisula, E., Misiak, A., Kalyva, E., Tsakiris, V., Kamio, Y., and Ishitobi, M. (2017). Examining cross-cultural differences in autism spectrum disorder: A multinational comparison from Greece, Italy, Japan, Poland, and the United States. European Psychiatry, 42, 70-76.

Maurer, C., Chambon, V., Bourgeois-Gironde, S., Leboyer, M., and Zalla, T. (2017). The influence of prior reputation and reciprocity on dynamic trust-building in adults with and without autism spectrum disorder. Cognition, 172, 1-10. Available at: <https://doi.org/10. 1016/j.cognition.2017.11.007> [Accessed 10 May 2020].

Meyns, P., Spank, J. V. D., Capiau, H., Cock, L. D., Steirteghem, E. V., Looven, R. V. D., and Waelvelde, H. V. (2019). Do a humanoid robot and music increase the motivation to perform physical activity? A quasi-experimental cohort in typical developing children and preliminary findings in hospitalized children in neutropenia. International Journal of Human-Computer Studies, 122, 90-102.

Murphy, C. M., Christakou, A., Giampietro, V., Brammer, M., Daly, E. M., Ecker, C., and Rubia, K. (2017). Abnormal functional activation and maturation of ventromedial prefrontal cortex and cerebellum during temporal discounting in autism spectrum disorder. Human Brain Mapping, 38 (11), 5343. Available at: < https://doi.org/10.1002/hbm.23718> [Accessed 10 May 2020].

Pe'rula-Martı́nez, R. I., Castro-Gonza'lez, A. I., Malfaz, M., Alonso-Martı́n, F., and Salichs, M. A. (2019). Bioinspired decision-making for a socially interactive robot. Cognitive System Research, 54, 287-301. 
INTERNATIONAL JOURNAL OF ACADEMIC RESEARCH IN BUSINESS AND SOCIAL SCIENCES

Vol. 10, No. 7, July, 2020, E-ISSN: 2222-6990 @ 2020 HRMARS

Prat, C. S., Stocco, A., Neuhaus, E., and Kleinhans, N. M. (2016). Basal ganglia impairments in autism spectrum disorder are related to abnormal signal gating to prefrontal cortex. Neuropsychologia 91, 268-281. <https://doi.org/10.1016/j.neuropsychologia.2016. 08.007> [Accessed 10 May 2020].

Raffard, S., Bortolon, C., Khoramshahi, M., Salesse, R. N., Burca, M., Marin, L., and Capdevielle, D. (2016). Humanoid robots versus humans: How is emotional valence of facial expressions recognized by individuals with schizophrenia? An exploratory study. Schizophrenia Research, 176, 506-513.

Robins, B., Dautenhahn, K., Boekhorst, R. T., and Billard, A. (2005). Robotic assistants in therapy and education of children with autism: can a small humanoid robot help encourage social interaction skills? Universal Access in the Information Society, 4, 105-120.

Bakar, R. A., and Zubir, H. A. (2018). Social stories: A creative way in minimizing disruptive behaviours among autistic learners. In R. A. Bakar, S. A. Rahim, \& F. N. Tazijan (Eds.), Creativity in teaching and learning: A blueprint for success, 9-14. Penang, Malaysia: Academy of Language Studies Publication Unit, Universiti Teknologi MARA Cawangan Pulau Pinang

Tordjmana, S. B., Celumec, M. P., Denisa, L., Motillona, T., and Keromnesa, G. (2019). Reframing schizophrenia and autism as bodily self-consciousness disorders leading to a deficit of theory of mind and empathy with social communication impairments. Neuroscience and Biobehavioral Reviews. 103, 401-413. <https://doi.org/10.1016/j.neubiorev.2019.04.007 $\geq$ [Accessed 10 May 2020].

Shamsudin, S., Yussof, H., Ismail, L., Hanapiah, F. A., Mohamed, S., Piah, H. A., and Zahari, N. I. (2012). Initial response of autistic children in human-robot interaction therapy with humanoid robot NAO. In: the 2012 IEEE 8th International Colloquium on Signal Processing and its Applications, Melaka: Malaysia.

Shamsuddin, S., Yussof, H., Ismail, L. I., Mohamed, S., Hanapiah, F. A., \& Zahari, N. I. (2012). Initial Response in HRI- a Case Study on Evaluation of Child with Autism Spectrum Disorders Interacting with a Humanoid Robot NAO. Procedia Engineering, 41, 1448-1455.

Fatahiyah, S. M., and Rukiah, M. (2010). Perubatan Menurut Perspektif Islam. Kuala Lumpur: Mashi Publication Sdn Bhd.

Sitimin, S. A., Fikry, A., Ismail, Z., and Hussein, N. (2017). Work-family Conflict among Working Parents of Children with Autism in Malaysia. In: 2017 IEEE International Symposium on Robotics and Intelligent Sensors, IRIS 2016, 17-20 December 2016, Tokyo: Japan.

Tanhan, A. (2019). Acceptance and commitment therapy with ecological systems theory: addressing muslim mental health issues and wellbeing. Journal of Positive Psychology \& Wellbeing, X, 1-23.

Tapus, A., Bandera, A., Vazquez-Martin, R., and Calderita, L. V. (2019). Perceiving the person and their interactions with the others for social robotics - A review. Pattern Recognition Letters, 118, 313.

Weng, Y.-H., Hirata, Y., Sakura, O., and Sugahara, Y. (2019). The religious impacts of taoism on ethically aligned design in HRI. International Journal of Social Robotics, 1-11.

Wood, L. J., Zaraki, A., Robins, B., and Dautenhahn, K. (2019). Developing kaspar: a humanoid robot for children with autism. International Journal of Social Robots, 1-18.

Wood, L. J., Robins, B., Lakatos, G., Syrdal, D. S., Zaraki, A., and Dautenhahn, K. (2019). Developing a protocol and experimental setup for using a humanoid robot to assist children with autism to develop visual perspective taking skills. Paladyn, Journal of Behavioral Robotics, 10(1), 167-179. 
INTERNATIONAL JOURNAL OF ACADEMIC RESEARCH IN BUSINESS AND SOCIAL SCIENCES

Vol. 10, No. 7, July, 2020, E-ISSN: 2222-6990 @ 2020 HRMARS

Yakub, F., Md. Khudzari, A. Z., and Mori, Y. (2014). Trends for practical rehabilitation robotics, current challenges and the future. International Journal of Rehabilitation Research, 37, 9-21.

Zhang, Y., Song, W., Tan, Z., Zhu, H., Wang, Y., Lam, C. M., and Yia, L. (2019). Could social robots facilitate children with autism spectrum disorders in learning distrust and deception? Computers in Human Behavior, 98, 140-149. 